\title{
Distribution and seasonal variation of trace metals in surface sediments of the Mandovi Estuary, West Coast of India. \\ Rengasamy Alagarsamy
}

Chemical Oceanography Division, National Institute of Oceanography, Donapaula, Goa- 403 004, India. Email: alagar@nio.org

Fax: 00 91-832-2450602/603

\begin{abstract}
The concentration and distribution of selected trace metals in surface sediments of the Mandovi estuary were studied to determine the extent of anthropogenic inputs from mining activities and to estimate the effects of monsoon on geochemical processes in this tropical estuarine system. Analysis of bulk sediments from the Mandovi estuary shows that the concentrations of iron, manganese, cobalt, copper, zinc and lead vary from 2.249.7\%; <Detection Limit (DL)-1.61\%; 2.5-45.3 $\mu \mathrm{g} \mathrm{g}^{-1} ; 11.5-77.5 \mu \mathrm{g} \mathrm{g}^{-1} ; 19.9-83.5 \mu \mathrm{g} \mathrm{g}^{-1}$; and 4.5-46.5 $\mu \mathrm{g} \mathrm{g}^{-1}$ respectively. An important observation is that, in general, lowest metal concentrations are found during the monsoon, compared to the pre- and postmonsoon. Comparison of the metal levels in the sediments from different areas of the estuary indicates that there is a detectable anthropogenic input to the Mandovi estuary. The enrichment of $\mathrm{Fe}$ and $\mathrm{Mn}$ reflects the intensity of anthropogenic inputs related to iron ore processing in the upstream region of the estuary, however, the highest enrichment levels were not found near the mouth region. Igeo values calculated for Fe (2.5) and $\mathrm{Mn}$ (3.4) showed higher values in the premonsoon period in the upstream region of the estuary than in the post monsoon and monsoon seasons. $\mathrm{Cu}$ and $\mathrm{Zn}$ enrichment in the river mouth region, associated with high organic carbon contents, is indicative of the influence of organic wastes from municipal sewage entering the estuary. The intermetallic relationship revealed the identical behaviour of metals during its transport in the estuarine environment.

Key words: trace metals; surface sediment; Mandovi estuary; anthropogenic input; mining; seasonal
\end{abstract}




\section{Introduction}

The Mandovi estuary is a tropical estuary on the west coast of India (Fig. 1) and its hydrological characteristics are governed by the monsoon regime. The estuarine channel of the Mandovi river is used to transport large quantities of iron and ferromanganese ores to Marmugao harbour (Arabian Sea) throughout the year. Its (length $\sim 50$ $\mathrm{km}$; area $\sim 29 \mathrm{~km}^{2}$; average depth $\sim 5 \mathrm{~m}$ ) width at the estuary is $3.2 \mathrm{~km}$ while, upstream, it narrows down to $0.25 \mathrm{~km}$. The rich iron and manganese ore deposits are considered as a natural wealth of Goa. Goa is an important mineral producing area on its west coast of India and its economy is dependent mainly on iron ore mining and its export. The mining activities in this region may influence the biological and geochemical conditions of the estuarine waters to a considerable extent. A study of the distribution and seasonal variations of trace metals in the sediments is important to the assessment of the probable influence of the mining of iron ore in this region on the estuarine environment. The measurement of trace element concentrations and distribution in the marine environment leads to better understanding of their behaviour in the aquatic environment and is important for detecting sources of pollution (Förstner and Wittmann, 1979). Studies of various physico-chemical, biological and mineralogical aspects of the Mandovi estuary have been carried out (Varma and Rao, 1975; Murthy et al., 1976; Qasim and Sen Gupta, 1981; Upadhyay and Sen Gupta, 1995, de Sousa, 1999) but limited data are available on

the distribution and seasonal variation of metal concentrations in the sediments of the Mandovi river. The trace metal data provide new information on the surface sediment geochemistry in the region whilst the study of element interrelationships, including organic carbon, gives information on their possible origin (Alagarsamy, 1991). The distribution of metals in sediments at 6 stations (Fig.1) in the Mandovi estuary has been examined, therefore, in order to enhance the data inventory for the region, characterize the geochemistry of $\mathrm{Fe}, \mathrm{Mn}, \mathrm{Co}, \mathrm{Cu}, \mathrm{Zn}$ and $\mathrm{Pb}$ in surficial sediments and to help understand the influence of anthropogenic activities and the monsoon on biogeochemical process in this tropical estuarine system. These impacts were assessed by means of the geoaccumulation index ( $\mathrm{I}_{\text {geo }}$, Müller, 1979) and $\mathrm{I}_{\text {geo }}$ classification is reported based on the chemical analysis of the bulk sediments. The $\mathrm{I}_{\text {geo }}$ has been widely utilised as a measure of pollution in freshwater (e.g. Müller, 1980; Singh et al., 1997; Kralik, 1999) and marine 
sediments (e.g. Stoffers et al., 1986; Bryan and Langston, 1992; Dickinson et al., 1996). Sampling was carried out monthly, over a period of one year from January to December 1985. However the data are presented as pooled values covering premonsoon (FebruaryMay), monsoon (June-September) and post monsoon (October-January) seasons.

\section{Materials and Methods}

\subsection{Collection and treatment of samples:}

Surface sediments were collected monthly, using a Van Veen Grab from 6 stations in the Mandovi estuary (Fig. 1) across the upper, mid, and lower regions, covering a distance of $\sim 50 \mathrm{~km}$ and a range of salinities from freshwater in the upstream area to seawater at the mouth. Sub samples were taken from the uppermost layer of the sediment taking care to minimise contamination. The samples were frozen after collection and later thawed, dried at $50-60^{\circ} \mathrm{C}$ in an oven and disaggregated in an ate mortar, before chemical treatment for total metal analysis. For each sample a known quantity $(\sim 1 \mathrm{~g})$ of sediment was digested with a solution of concentrated $\mathrm{HClO}_{4}(2 \mathrm{ml})$ and $\mathrm{HF}(10 \mathrm{ml})$ to near dryness. Subsequently, a second addition of $\mathrm{HClO}_{4}(1 \mathrm{ml})$ and $\mathrm{HF}$ $(10 \mathrm{ml})$ was made and the mixture was evaporated to near dryness. Finally, $\mathrm{HClO}_{4}(1 \mathrm{ml})$ alone was added and the sample was evaporated until white fumes appeared. The residue was dissolved in concentrated $\mathrm{HCl}$ and diluted to $25 \mathrm{ml}$ (Tessier et al., 1979).

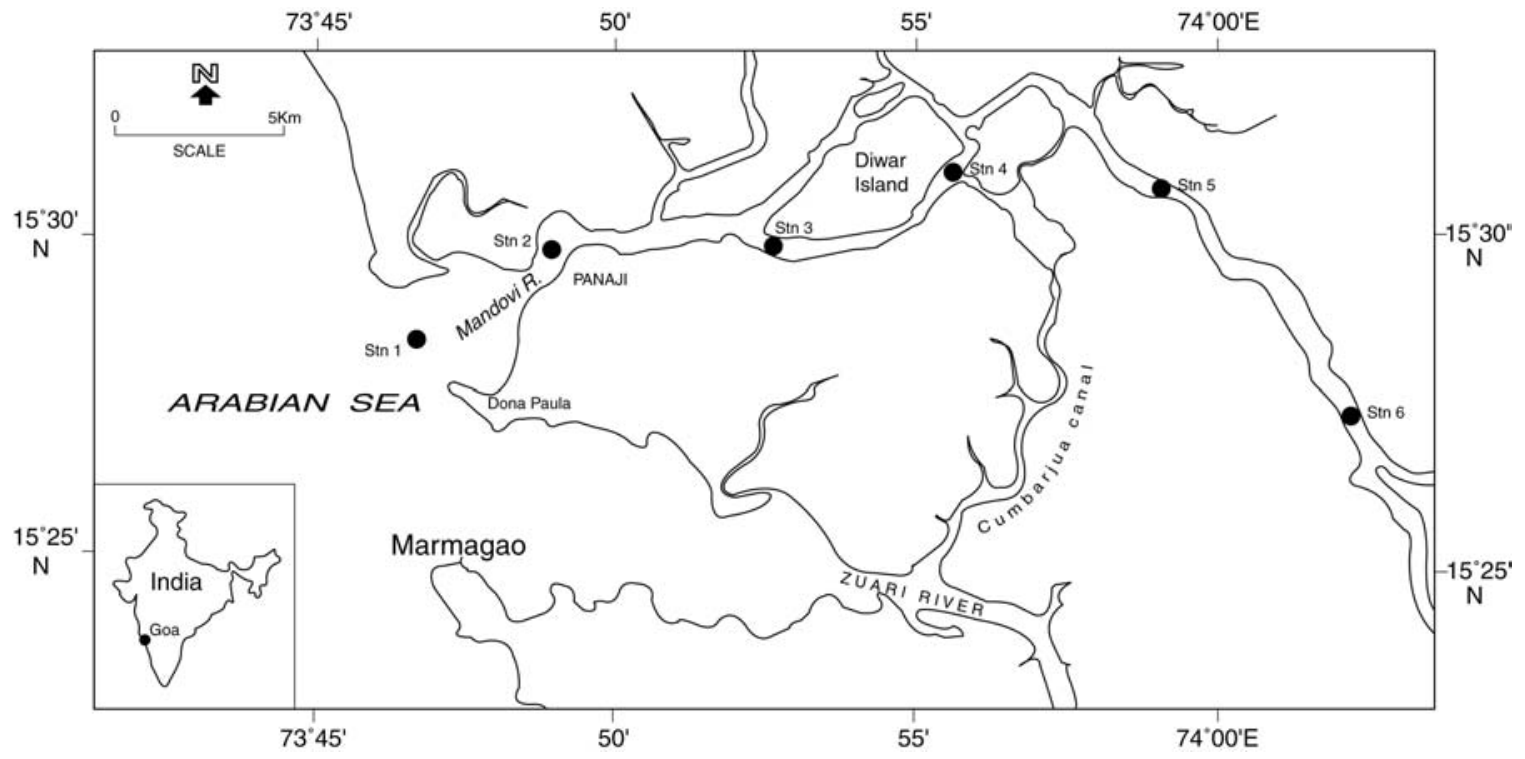

Fig.1. Location of sampling sites in the Mandovi estuary 


\subsection{Analysis of Trace Metals:}

Trace metal concentrations ( $\mathrm{Fe}, \mathrm{Mn}, \mathrm{Cu}, \mathrm{Co}, \mathrm{Zn}$ and $\mathrm{Pb}$ ) were measured using a flame atomic absorption spectrophotometer (AAS, Perkin-Elmer Model 5000). The accuracy of the analytical procedures was assessed using the certified reference material BCR-1 and yielded results within the reference value range (Flanagan, 1973). For Fe, $\mathrm{Mn}, \mathrm{Cu}$ and $\mathrm{Zn}$ the reproducibility, expressed as the coefficient of variation, was $<5 \%$; for $\mathrm{Co}$ and $\mathrm{Pb}$ it was 10 and 13\% respectively.

\section{Results and discussion}

Concentration ranges in the sediments were: Fe 2.2-49.7\%; Mn $<$ DL-1.61\% (DL referred from Perkin-Elmer Manual as recommended); Co 2.5-45.3 $\mu \mathrm{g} \mathrm{g}^{-1}$; $\mathrm{Cu}$ 11.5-77.5 $\mu \mathrm{g} \mathrm{g}^{-1}$; $\mathrm{Zn} \mathrm{19.9-83.5} \mu \mathrm{g} \mathrm{g}^{-1}$; and $\mathrm{Pb} 4.5-46.5 \mu \mathrm{g} \mathrm{g}^{-1}$. TOC values were referred from earlier studies (Alagarsamy, 1991).

\section{1. $\mathrm{Fe}$}

The range in sedimentary iron values of between $2.2 \%$ and $49.7 \%$ are somewhat higher than that reported from other Indian estuaries (Table 1). During the premonsoon period, higher concentrations of iron are observed (Fig. 2a) throughout the estuary, which may be attributed to high spillage during transportation of iron and ferromanganese ores down the Mandovi estuary. Kamat and Sankaranarayanan (1975) observed a high value (5-44 $\mathrm{mg}^{-1}$ ) of particulate iron in the Mandovi estuary and low value in the nearshore water $\left(0.65-12.7 \mathrm{mg} \mathrm{l}^{-1}\right)$.

\section{2. $M n$}

Compared with other seasons, the Mn concentrations in the sediment were generally highest during the premonsoon period (Fig. 2b). Values showed an increase from the mouth to the freshwater upper regions as the water concentrations ranged varied from 6.2 to $102.2 \mu \mathrm{g} \mathrm{l}^{-1}$ (Zingde et al., 1976). The high Mn concentrations observed for both water and sediment are related to high levels of manganese in the surrounding ore bearing landmass (Zingde et al., 1976) as the rivers flowing through the ore bearing (iron and manganese) terrain might be picking up the element (Sankaranarayanan and Reddy 1973). Zingde et al., (1976) observed a decrease in Mn concentration for water from 88.9 
$\mu \mathrm{g} 1^{-1}$ at station 6 to only $10.9 \mu \mathrm{g}^{-1}$ at the river mouth. Similarly sediment manganese also decreases from $0.76 \%$ upstream (St. 6) to $0.23 \%$ at the mouth of the estuary (based on the pooled values of monthly data for each seasons and stations). An important observation is that almost entire iron ore gets deposited in the upstream region and in contrast, only about $7 \%$ manganese is found in the sediments compared to the original composition of these ores as reported by Dixit et al. (1985).

\subsection{Co}

Generally, cobalt concentrations were the highest during the premonsoon period decreasing through to the post monsoon (Fig. 2c). No strongly elevated concentrations of Co were observed, although Co is apparently enriched above natural values. It should be noted that the choice of reference value for normalisation alters the degree of enrichment.

\section{4. $\mathrm{Cu}$}

When the annual average for $\mathrm{Cu}$ in sediment was computed, a general increase from the marine to the riverine zone was seen. Sankaranarayanan and Reddy (1973) reported low concentrations of copper in water $\left(2-14 \mu \mathrm{g}^{-1}\right)$ in the Mandovi river as compared to Zuari river. There is a general trend observed that for copper (except for station 4) decreasing its concentration from the pre-monsoon to the monsoon and increasing again to the post-monsoon. During the monsoon period, when freshwater discharge is maximum, the copper level was $74 \mu \mathrm{g} \mathrm{l}^{-1}$ (Sankaranarayanan and Reddy, 1973) and dissolved labile copper concentrations were also high both at the surface and in bottom waters of the Mandovi estuary in the river mouth (George et al. 1984). Higher level of sediment concentration (77.5 $\left.\mu \mathrm{g} \mathrm{g}^{-1}\right)$ was observed during August. It may be mentioned here that there is no significant relation between salinity and the copper concentration for inshore and estuarine waters along the central west coast of India (Sankaranarayanan and Reddy, 1973). The values of copper concentrations in the sediment of the Mandovi estuary varied from 11.5 to $77.5 \mu \mathrm{g} \mathrm{g}^{-1}$ and are lower or equal to those reported from various other estuarine sediments in India (Table 1). 
As similar to $\mathrm{Cu}$, there is a general trend observed that for zinc, decreasing its concentration from the pre-monsoon to the monsoon and increasing again to the postmonsoon. Zinc concentrations in the Mandovi estuarine sediments showed generally higher values than $\mathrm{Cu}$. Zinc can enter the aquatic environment from a number of sources including industrial discharges, sewage effluent and runoff (Boxall et al., 2000). Zingde et al. (1976) reported that the average concentration for $\mathrm{Zn}\left(18.7 \mu \mathrm{g} \mathrm{l}^{-1}\right)$ in estuarine waters around Goa. A gradual decrease of dissolved metals towards the Arabian Sea is observed (Zingde et al., 1976). This is particularly recognizable for $\mathrm{Zn}$, which decreases from $20.3 \mu \mathrm{g} \mathrm{l}^{-1}$ at station 6 to $7.2 \mu \mathrm{g}^{-1}$ at the mouth (Zingde et al., 1976). The average concentrations of $\mathrm{Zn}$ in sediments in the mouth region are $67.8 \mu \mathrm{g} \mathrm{g}^{-1}, 41.4 \mu \mathrm{g} \mathrm{g}^{-1}$ and $49.0 \mu \mathrm{g} \mathrm{g}^{-1}$ in premonsoon, monsoon and post monsoon seasons respectively. Input of organic wastes into the estuary, which comes from municipal sewage, contributes to the $\mathrm{Zn}$ increase in sediments. This source also contributes to the high organic carbon content where a maximum value of 3\% was observed in the mouth region (Alagarsamy, 1991).

\section{6. $\mathrm{Pb}$}

In the present study lead concentrations varied from 4.5 to $46.5 \mu \mathrm{g} \mathrm{g}^{-1}$. Lead occurs in nature at an average crustal abundance of $16 \mu \mathrm{g} \mathrm{g}^{-1}$. Like soils in the terrestrial system, sediments are the primary sinks for lead in the aquatic environment. For deep ocean sediments the natural average value is about $47 \mu \mathrm{g} \mathrm{g}^{-1}$ but with wide fluctuations (Craig, 1980). Lead values in bay, estuarine and other coastal sediments (marsh environments) have been much altered by man's activities. The average $\mathrm{Pb}$ levels in Indian river sediment is about $14 \mu \mathrm{g} \mathrm{g}^{-1}$ (Dekov et al., 1999), which is lower than the world average. The average $\mathrm{Pb}$ in Indian river particulates are $\sim 51 \mu \mathrm{g} \mathrm{g}^{-1}$ (Dekov et al., 1999) which are also lower than the world river particulates of $150 \mu \mathrm{g} \mathrm{g}^{-1}$ (Martin and Meybeck, 1979). The present study showed that the variation of lead in the upstream regions and during post monsoon is small (Fig. 2f). Nolting et al., (1996) observed that the low and constant $\mathrm{Pb}$ concentrations indicating the minor importance of anthropogenic input from the Laptev Sea in contrast to other areas of world as anthropogenic inputs are considered to be the major source of elevated $\mathrm{Pb}$ concentrations in marine sediments (Nolting et al., 1999). 


\subsection{Index of geoaccumulation}

Possible sediment enrichment of metals was evaluated in terms of the $\mathrm{I}_{\text {geo }}$ of Müller (1979). The formula used for the calculation of $\mathrm{I}_{\text {geo }}$ is: $\log _{2}(\mathrm{Cn} / 1.5 * \mathrm{Bn})$, where $\mathrm{Cn}$ is the measured content of element " $\mathrm{n}$ ", and $\mathrm{Bn}$ the element's content in "average shale" (Turekian and Wedepohl, 1961). The geoaccumulation index ( $\left.\mathrm{I}_{\mathrm{geo}}\right)$ was originally defined by Müller (1979) for a quantitative measure of the metal pollution in aquatic sediments (Ridgway and Shimmield, 2002) and is shown for the Mandovi sediments in the Figs. 3 (a-f). Elevated $\mathrm{I}_{\text {geo }}$ values identified for $\mathrm{Fe}$ and $\mathrm{Mn}$ in the same areas indicate that surface sediments are contaminated to some extent, most probably as a result of anthropogenic activities. Igeo values calculated for Fe (2.5) and Mn (3.4) showed higher values in the premonsoon period in the upstream region of the estuary than in the post monsoon and monsoon seasons. This trace metal enrichment is attributed to iron ore processing in the higher reaches. The sediments of the Mandovi estuary were found to be enriched in Fe and Mn according to the Igeo classification (Table 2). The sediment metal concentrations found in this study were of the same order of magnitude as metal concentrations found by diverse authors in sediments of Indian estuaries (Biksham and Subramanian, 1988; Ramesh et al., 1990; Subramanian et al., 1988; Ramanathan et al., 1993) except for $\mathrm{Fe}$ and $\mathrm{Mn}$.

\subsection{Factors controlling the distribution of trace metals in Mandovi estuary}

It is well established that organic matter contents are important controlling factors in the abundance of trace metals (Rubio et al., 2000). The organic carbon content of the sediments showed that $\mathrm{Co}, \mathrm{Cu}, \mathrm{Zn}$ and $\mathrm{Pb}$ are significantly correlated and negatively correlated with $\mathrm{Fe}$ and $\mathrm{Mn}$ (Table 3). The statistical analysis of intermetallic relationship revealed the high degree of correlation and significant regression relation among the metals indicate the identical behaviour of metals during its transport in the estuarine environment. There are significant inter-elemental correlations (e.g., $\mathrm{Fe}-\mathrm{Mn}, \mathrm{Fe}-\mathrm{Cu}, \mathrm{Co}-$ $\mathrm{Cu}, \mathrm{Co}-\mathrm{Zn}, \mathrm{Cu}-\mathrm{Zn}, \mathrm{Cu}-\mathrm{Pb}, \mathrm{Zn}-\mathrm{Pb}$ ) and inverse correlations (Mn-Zn) were observed in the estuarine sediments (Table 3). In the present study, the poor association of Mn with other metals $(\mathrm{Co}$ and $\mathrm{Pb})$ suggests that $\mathrm{Mn}$-oxide may be a only a minor host phase for these elements in the estuarine environment. 


\section{Conclusions}

The elevated $\mathrm{I}_{\text {geo }}$ values identified for Fe and $\mathrm{Mn}$ in the Mandovi estuary indicate that the surface sediments are moderately or strongly contaminated to some extent, probably as a result of anthropogenic activities and provide a useful means of distinguishing between the natural and anthropogenic sources of metals entering the coastal zone through river inputs. It is observed that, in general, lowest metal concentrations are found during the monsoon, compared to the pre- and post-monsoon. The comparison of the metal levels in the sediments from different areas of the estuary indicated that there is a detectable anthropogenic input to the Mandovi estuary. $\mathrm{Cu}$ and $\mathrm{Zn}$ showed the influence of organic wastes from municipal sewage entering the estuary, in the river mouth region. Correlations with organic carbon have allowed to understand the distribution of metals and its association within the sediments. It is proposed that continuous monitoring and further studies in the area should be carried out in the near future to ascertain long-term effects of anthropogenic impact and to assess the effectiveness of minimising the human activity to upgrade the marine environment in the Mandovi estuary on the west coast of India as the mining activities influence the geochemical process in the estuarine systems.

\section{Acknowledgements}

The author would like to thank Dr. M.D. Rajagopal for the samples, G. Parthiban for assistance in the analysis, Pawaskar Pramod for drafting Figure1, Dr. S.G. Dalal for assistance in the statistical analysis and the Director, NIO for providing facilities to carry out this work. I also thank anonymous reviewers for helpful comments. This is NIO Contribution No. 4076. 


\section{References}

Alagarsamy, R., 1991. Organic carbon in the sediments of Mandovi estuary, Goa. Indian Journal of Marine Sciences 20, 221-222.

Biksham, G., Subramanian, V., 1988. Elemental composition of Godavari sediments (Central and Southern Indian Subcontinent). Chemical Geology 70, 275-286.

Boxall, A.B.A., Comber, S.D., Conrad, A.U., Howcroft, J., Zaman, N., 2000. Inputs, Monitoring and Fate Modelling of Antifouling Biocides in UK Estuaries. Marine Pollution Bulletin 40, 898-905.

Bryan, G.W., Langston, W.J., 1992. Bioavailability, accumulation and effects of heavy metals in sediments with special reference to United Kingdom estuaries: a review. Environmental Pollution 76, 89-131.

Craig, P.J., 1980. Metal cycles and biological methylation. In: Hutzinger, O (Ed.), Handbook of Environmental Chemistry, Vol. 1, Part-A, The Natural Environment and the Bigeochemical Cycles. Springer-Verlag Berlin Heidelberg, pp.169-227.

Dekov, V.M., Subramanian, V., Van Grieken, R., 1999. Chemical composition of riverine suspended matter and sediments from the Indian sub-continent. In: Ittekkot, V., Subramanian, V. and Annadurai, S. (Eds.), Biogeochemistry of Rivers in Tropical South and Southeast Asia. Heft 82, SCOPE Sonderband, Mitteilugen aus dem Geologisch-Paläontolgischen Institut der Universität, Hamburg, pp. 99-109.

de Sousa, S.N., 1999. Effect of mining rejects on the nutrient chemistry of Mandovi estuary, Goa. Indian Journal of Marine Sciences 28, 355-359.

Dickinson, W.W., Dunbar, G.B., McLeod, H., 1996. Heavy metal history from cores in Wellington Harbour, New Zealand. Environmental Geology 27, 57-69.

Dixit, R.L.N., Sriram, K., Jena, B.K. 1985. Deep weathering crusts and supergene ore deposits of Goa. In: Geological Survey of India, Calcutta (Ed.), Earth Resources for Goa's Development. pp. 603-604.

Flanagan, F.J., 1973. 1972 values for international geochemical reference samples. Geochimica Cosmochimica Acta 37, 1189-1200.

Förstner, U., Wittmann, G.T.W., 1979. Metal pollution in the aquatic environment. Springer-Verlag, Berlin Heidelberg, pp. 486.

George, M.D., Sawkar, K., Reddy, C.V.G., 1984. Determination of $\mathrm{Cd}, \mathrm{Pb}$ and $\mathrm{Cu}$ in Mandovi Estuary by Differential Pulse Anodic Stripping Voltammetry. Indian Journal of Marine Sciences13, 64-68. 
Kamat, S.B., Sankaranarayanan, V.N., 1975. Concentration of particulate iron in estuarine \& coastal waters of Goa. Indian Journal of Marine Sciences 4, 34-38.

Kralik, M., 1999. A rapid procedure for environmental sampling and evaluation of polluted sediments. Applied Geochemistry 14, 807-816.

Martin, J.M., Meybeck, M., 1979. Elemental mass-balance of material carried by world major rivers. Marine Chemistry 7, 173-206.

Müller, G., 1979. Schwermetalle in den sedimenten des Rheins - Veränderungen seit 1971. Umschau 79, 778-783.

Müller, G., 1980. Schwermetalle in den sedimenten des Elbe bei Stade Naturwissenschaften 67, 560-561.

Murthy, C.S., Das, P.K., Nair, R.R., Veeraya, M., Varadachari, V.V.R., 1976. Circulation and sedimentation processes in and around the Aguada Bay. Indian Journal of Marine Sciences 5, 9-17.

Nolting, R.F. van Dalen, M., Helder, W., 1996. Distribution of trace and major elements in sediment and pore waters of the Lena Delta and Laptev Sea. Marine Chemistry 53, 285-299.

Nolting, R.F. Ramkema, A., Everaarts, J.M., 1999. The geochemistry of $\mathrm{Cu}$, $\mathrm{Cd}, \mathrm{Zn}, \mathrm{Ni}$ and $\mathrm{Pb}$ in sediment cores from the continental slope of the Banc d,Arquin (Mauritani). Continental Shelf Research 19, 665-691.

Qasim, S.Z., Sen Gupta, R., 1981. Environmental characteristics of the Mandovi-Zuari estuarine system in Goa. Estuarine, Coastal and Shelf Science 13, 557-578.

Ramanathan, A.L., Vaithiyanathan, P., Subramanian, V., Das, B.K., 1993. Geochemistry of the Cauvery estuary, East Coast of India. Estuaries 16, 459-474.

Ramesh, R., Subramanian, V., Van Grieken, R., 1990, Heavy metal distribution in sediments of Krishna river basin, India. Environmental Geology Water Science 15, 207-216.

Ridgway, J., Shimmield, G., 2002. Estuaries as respositories of historical contamination and their impact on shelf seas. Estuarine, Coastal and Shelf Science 55, 903-928.

Rubio, B., Nombela, M.A., Vilas, F., 2000. Geochemistry of major and trace elements in sediments of the Ria de Vigo (NW Spain): an assessment of metal pollution. Marine Pollution Bulletin 40, 968-980.

Sankaranarayanan, V.N., Reddy C.V.G., 1973. Copper content in the inshore and estuarine waters along the central west coast of India, Current Science 42, 223-224. 
Singh, M., Ansari, A.A, Müller, G., Singh, I.B., 1997. Heavy metals in freshly deposited sediments of the Gomati River (a tributary of the Ganga River): Effects of human activities. Environmental Geology 29, 246-252.

Stoffers, P., Glasby, G.P., Wilson, C.J., Davies, K.R., Walter, P., 1986. Heavy metal pollution in Wellington Harbour. New Zealand Journal of Marine Freshwater Research 20, 495-512.

Subramanian, V., Jha, P.K., Van Grieken, R., 1988. Heavy metals in the Ganges estuary. Marine Pollution Bulletin 19, 290-293.

Tessier, A., Campbell, P.G.C., Bisson, M., 1979. Sequential extraction procedure for the speciation of particulate trace metals. Analytical Chemistry 51, 844-851.

Turekian, K.K., Wedepohl, K.H., 1961. Distribution of the elements in some major units of the earth's crust. Bulletin Geological Society of America 72, 175-192.

Upadhyay, S., Sen Gupta, R., 1995. The behaviour of aluminium in waters of the Mandovi estuary, west coast of India. Marine Chemistry 51, 261-276.

Varma, K.K., Rao, L.V.G., 1975. Temporal and Spatial variations in hydrographic conditions of Mandovi estuary. Indian Journal of Marine Sciences, 4, 11-17.

Zingde, M.D., Singbal, S.Y.S., Moraes C.F., Reddy C.V.G., 1976. Arsenic, Copper, Zinc and Manganese in the marine flora and fauna of coastal and estuarine waters around Goa. Indian Journal of Marine Sciences 5, 212-217. 


\section{Table 1}

Comparison of the metal levels ( $\mu \mathrm{g} \mathrm{g}^{-1}$ dry wt. except Fe in \%) in the estuarine sediments from different areas of India (DL - Detection Limit)

\begin{tabular}{|c|c|c|c|c|c|c|c|}
\hline Location & $\begin{array}{l}\mathrm{Fe} \\
(\%)\end{array}$ & $\mathrm{Mn}$ & $\mathrm{Co}$ & $\mathrm{Cu}$ & $\mathrm{Zn}$ & $\mathrm{Pb}$ & Reference \\
\hline Cauvery estuary & 1.76 & 319 & 64 & 12 & 26 & 10 & $\begin{array}{l}\text { Biksham and Subra- } \\
\text { manian, } 1988\end{array}$ \\
\hline Ganges estuary & 3.1 & 553 & 36 & 26 & 71 & 29 & $\begin{array}{l}\text { Subramanian et al., } \\
1988\end{array}$ \\
\hline Krishna estuary & 4.23 & 1040 & 47 & 49 & 31 & 9 & $\begin{array}{l}\text { Biksham and Subra- } \\
\text { manian, } 1988\end{array}$ \\
\hline Godavari estuary & 5.7 & 1070 & 47 & 82 & 54 & 11 & Ramesh et al., 1990 \\
\hline Narmada estuary & 3.14 & 514 & 29 & 46 & 50 & 5 & $\begin{array}{l}\text { Biksham and } \\
\text { manian, } 1988\end{array}$ \\
\hline Tapti estuary & 1.09 & 1300 & 36 & 126 & 118 & 5 & $\begin{array}{l}\text { Biksham and } \\
\text { manian, } 1988\end{array}$ \\
\hline Mandovi estuary & $\begin{array}{l}2.2- \\
49.7\end{array}$ & $\begin{array}{l}<\mathrm{DL}- \\
1.61 \%\end{array}$ & $\begin{array}{l}2.5- \\
45.3\end{array}$ & $\begin{array}{l}11.5- \\
77.5\end{array}$ & $\begin{array}{l}19.9- \\
83.5\end{array}$ & $\begin{array}{l}4.5- \\
46.5\end{array}$ & This study \\
\hline
\end{tabular}

Table 2

Description of sediment quality. $\mathrm{I}_{\text {geo }}$ classification (Müller, 1979)

\begin{tabular}{lll}
\hline$I_{\text {geo }}$ & $I_{\text {geo }}$ class & Description of sediment quality \\
\hline$>5$ & 6 & Extremely contaminated \\
$4-5$ & 5 & Strongly to extremely strongly contaminated \\
$3-4$ & 4 & Strongly contaminated \\
$2-3$ & 3 & Moderately to strongly contaminated \\
$1-2$ & 2 & Moderately contaminated \\
$0-1$ & 1 & Uncontaminated to moderately contaminated \\
$<0$ & 0 & Uncontaminated \\
\hline
\end{tabular}




\section{Table 3}

Correlation coefficient matrix (r) for trace metals and organic carbon in surface sediments of Mandovi estuary ( $\mathrm{r}>0.23, \mathrm{p}<0.05, \mathrm{n}=69$ Bold figures are significant)

\begin{tabular}{llllllll}
\hline Elements & $\mathrm{Fe}$ & $\mathrm{Mn}$ & $\mathrm{Co}$ & $\mathrm{Cu}$ & $\mathrm{Zn}$ & $\mathrm{Pb}$ & $\mathrm{TOC}$ \\
\hline $\mathrm{Fe}$ & 1 & $\mathbf{0 . 7 4}$ & 0.19 & $\mathbf{0 . 4 6}$ & -0.16 & 0.02 & $\mathbf{- 0 . 3 3}$ \\
$\mathrm{Mn}$ & & 1 & 0.23 & $\mathbf{0 . 3 8}$ & $\mathbf{- 0 . 4 8}$ & -0.17 & $\mathbf{- 0 . 4 6}$ \\
$\mathrm{Co}$ & & & 1 & $\mathbf{0 . 5 2}$ & $\mathbf{0 . 5 9}$ & -0.22 & $\mathbf{0 . 2 7}$ \\
$\mathrm{Cu}$ & & & 1 & 0.16 & 0.20 & $\mathbf{0 . 4 1}$ \\
$\mathrm{Zn}$ & & & & & 1 & 0.12 & $\mathbf{0 . 6 2}$ \\
$\mathrm{Pb}$ & & & & & & 1 & $\mathbf{0 . 4 2}$ \\
\hline
\end{tabular}



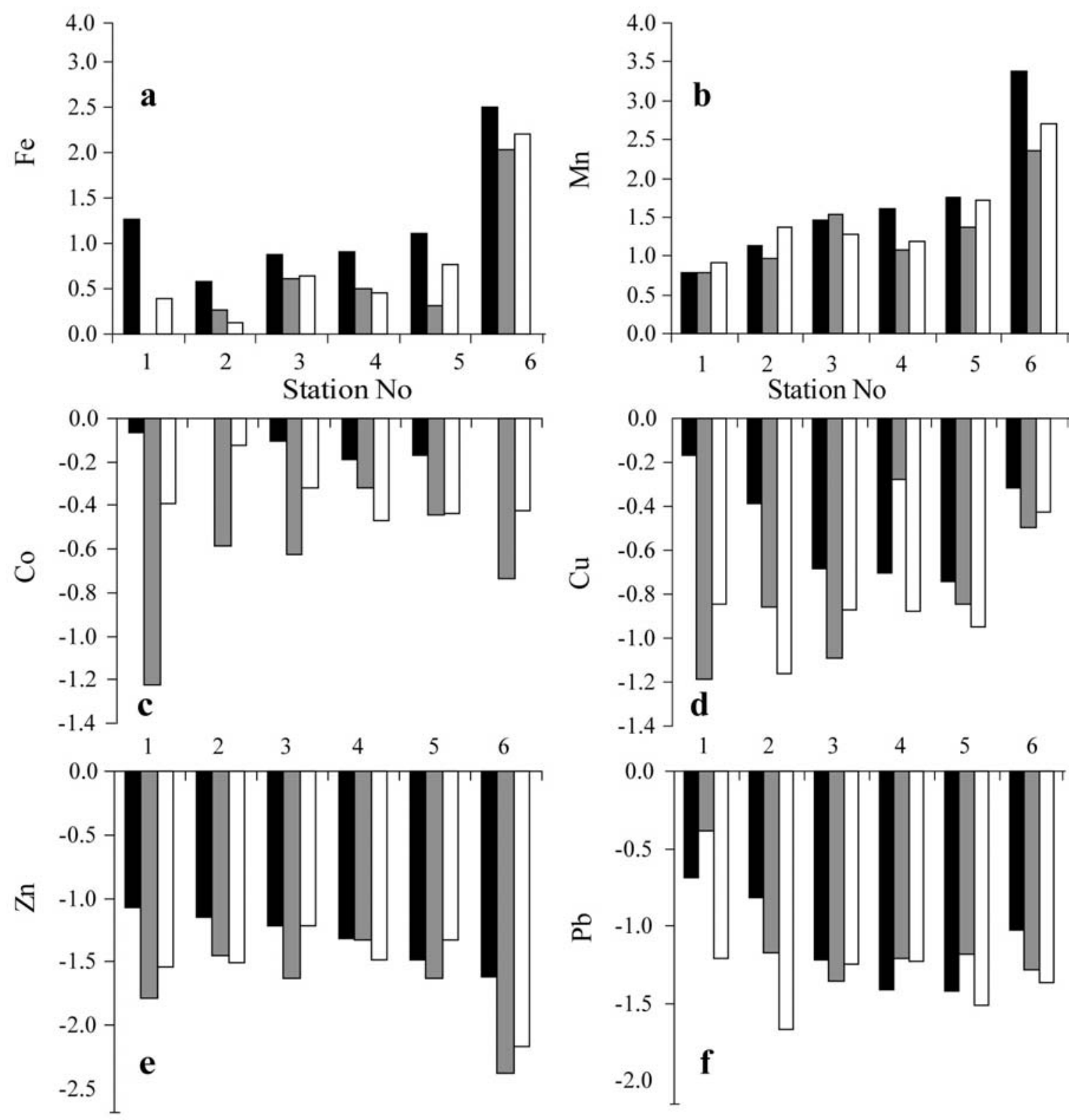

— Premonsoon $\square$ Monsoon $\square$ Postmonsoon

Fig. 2. Seasonal variation of $\mathrm{Fe}(\mathrm{a}), \mathrm{Mn}(\mathrm{b}), \mathrm{Co}(\mathrm{c}), \mathrm{Cu}(\mathrm{d}), \mathrm{Zn}(\mathrm{e})$ and $\mathrm{Pb}(\mathrm{f})$ in the Mandovi estuarine sediment. 

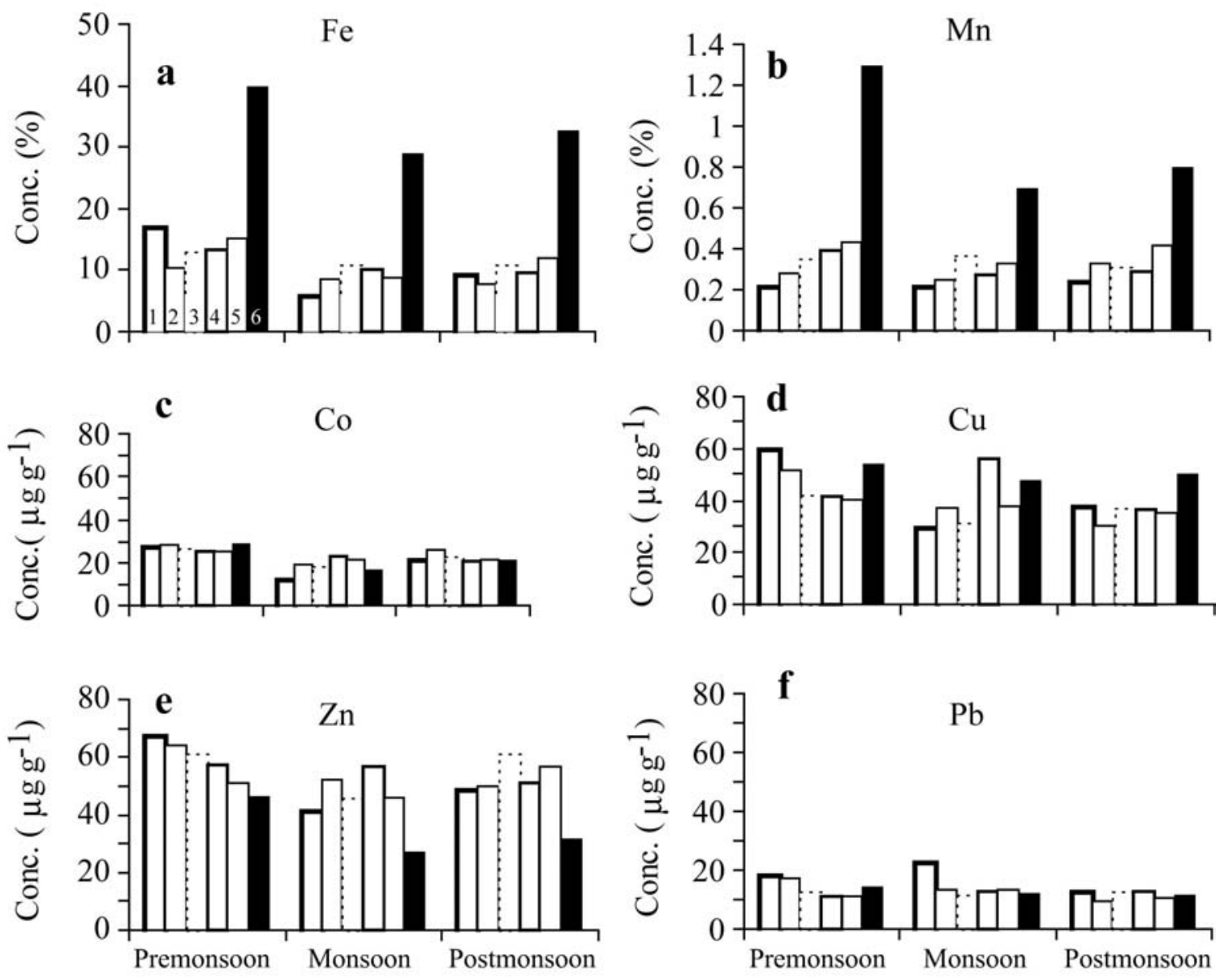

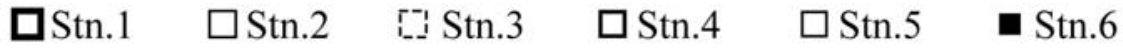

Fig. 3. Plots showing (a-f) $I_{\text {geo }}$ seasonal values for each metal. 